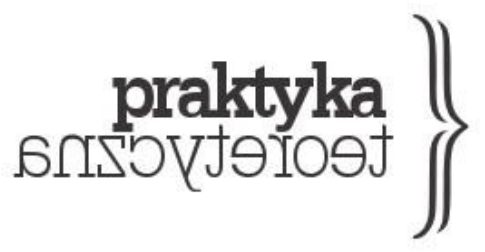

\title{
How COMmunists WANTED TO REMEMBER COMMUNiSM
}

\author{
AGATA ZYSIAK
}

\begin{abstract}
This is a review essay discussing an edited volume titled Historical Memory of Central and East European Communism (eds. Agnieszka Mrozik and Stanislav Holubec, Routledge 2018).
\end{abstract}

Keywords: memory politics, communism, state-socialism, review essay 
Starting a book about East Central Europe and communism with a quote from George Orwell seems to be evergreen, but also introduces a certain way of thinking about the period and raises certain questions: shall we get yet another totalitarian argument about powerful propaganda and omnipotent ideology arranging the memory and past of captive nations? Will it offer anything new in a vast spectrum of memory studies on and in Eastern Europe? The field of memory politics is difficult because so much has already been written, and as with this volume, a large part of the literature on memory policies are edited volumes that gather together localized historical case studies. Since the 1990s, the topics of memory and historical policies in East Central Europe have become an intensely covered topic to such an extent that they might become the region's specialization (just to mention a few from last 5 years: Dobre and Ghita 2017; Wulf 2016; Törnquist Plewa 2016; Sindbæk Andersen and Törnquist Plewa 2016; Pakier and Wawrzyniak 2016; Mitroiu 2015; Bernhard and Kubik 2014; Ochman 2013; Mink and Neumayer 2013). In Poland, both academic interests fuelled a rise in this thematic area as well as institutional shifts, like the establishment of the Institute of National Remembrance in 1998 or later debates about the Fourth Polish Republic (a symbolic political project, an alternative to the "post-communist" Third Republic) or recent events like an attempt to introduce the Holocaust Law (criminalization of making accusations that the Polish nation was responsible or complicit in Nazi crimes). Therefore, it is not easy to still say something new and revealing in this field - especially in an edited volume like the one discussed here.

The book is the result of the conference, "Historical Memory of Central and East European Communism", organized in 2015 in Prague by the Association for Leftist Theory SOK; Association for European Dialog (a member of the Transfrom! network) and the Rosa Luxemburg Foundation. It gathers contributions from over half of the conference participants: eleven articles from mostly young researchers divided into an introduction and three sections. I mention the age, because it is much more difficult to publish an edited volume with mostly $\mathrm{PhD}$ students or early $\mathrm{PhDs}$ as contributors. The volume offers a perspective on the communist movement and memory policies of both Eastern and Western European communists. The editors define their scope of interest as the following: "communism was and is remembered by various political organizations, politicians and other social actors who call themselves "communist(s). (...) In this volume, we hope to compensate this lack (of communist memory - AZ)". (p. 2). A truly interesting choice was to include communists from Western Europe along with experiences from the so-called Soviet Bloc. The volume's focus is not on how communism itself was remembered, but on the reconstruction of historical memory and narratives characteristic for the movement itself - in the West, during particular periods of state-socialism and after their collapse.

Actually, a reader might be slightly misled by the publisher's description, which presents the book as a coherent story of how the communist movement and its historical identity 
developed. The chronology of the volume seems to proceed consistently, starting with Karl Marx and Friedrich Engels; the recreation the movement's "victorious milestones" like the October Revolution or the Great Patriotic War; the Stalinist period; reinterpretations of 1956 and repressed events like Katyń and the Prague Spring which led to a crisis of state socialism in the late 1980s and finally ending with the reformulation or rejection of communist selfidentity. In actuality, the book does not offer coherence so much as a random assortment of cases and themes. The most interesting decision was to include Western communists but they actually appear only in the book's first section, titled "Memory of the Left in Post-Socialist Europe" and focused on the self-identity of the contemporary Left. The second section focuses on memorial landscapes through examining case studies. The third and final section, titled "Communist Politics of Memory Before 1989", concentrates on state-socialism's internal practises of memory politics revealing its pluralism, conflicts and changes over time.

The introduction, written by the volume's editors, Agnieszka Mrozik, assistant professor at the Polish Academy of Sciences in Warsaw, and Stanislav Holubec, associate professor at the University of České Budějovice and University of Hradec Králové, offers the story of the rise and development of what can be called "communist memory". It is actually a serious attempt to find coherence in the presented material, but many themes will appear only here. Therefore, one should read it less as a shortcut for navigating through the volume, and rather as a manifesto and historical reconstruction of communist memory politics. The introduction provides background for the other contributions, which focus more profoundly on later periods.

The origins of communist memory were being reconstructed from the $19^{\text {th }}$ century with Engels's attempts to protect Marx's heritage and the first commemorative decisions within the communist movement (like May Day celebrations planned to displace religious festivities in the 1890s and the introduction of the International Women's Day in the 1900s). After 1917, communist historical narratives were mainly produced by Bolsheviks and included events such as the removal of tsarists monuments, new celebrations and commemorations related to recent events and biographical information on leaders' lives (p. 4). Later developments during both the interwar period and the Second World War were still presented mainly from the Russian perspective, while the rest of Eastern Europe received more attention only later, when the People's Republics were established. I especially appreciate the inclusion of Western communist parties. The authors point out that after the war, the recent martyrology of the antiNazi resistance rather than traditions of interwar strikes became central for memory of the communist movement in the West. Mrozik and Holubec argue that the end of Stalinism in the 1950s began a deeper split between the East and West. Communist parties outside the Soviet Bloc started to develop their own historical narratives, often critical of the Soviet Union. At the same time, de-Stalinization opened more space for local variants of historical narratives in 
the Eastern Bloc, including dangerous flirtations with nationalism and antisemitism. The overview of topics mentioned here is satisfactorily broad and rich: from the cult of cosmonauts and the realisation of modernization's dream in dams and canals to Third World relations and anti-colonial struggles. The authors point out that Soviet history was represented a in nonlinear manner, without rupture events or conflicts, but as "a cyclic structure of constantly repeating non-events heading towards the horizon of communism" (p. 11). At the same time, the volume's contributions well prove that the story is much more multi-layered, diverse and pluralistic, full for conflicts, shifts and reinterpretations.

The introduction also offers some revisionist postulates like the recognition of achievements of Soviet modernization and a generous interpretation of the system's collapse (pp. 13-14). All in all, it can be viewed as the volume's manifesto since there are no other summaries, conclusions or separate introductions to the book's specific sections. The history of memory politics offered here is therefore the most coherent overall and ordered part of the volume, as the rest of the chapters provide rather disparate, if not isolated contributions, with their own theoretical and methodological choices, not necessarily comparable scopes of interest and diverse selection of materials and time periods. In order to address the broad and diverse range of the book and do justice to all its contributors, I will very briefly discuss all eleven chapters.

The first section is the most contemporary one and it alone deals with "non-Soviet" contexts. It examines the post-1989 memory of communism and the self-identity of the Left in the former West. The scope of interests seems wide and the span of its timeline is from the $19^{\text {th }}$ century to recent events like financial crisis and Syriza's 2015 negotiations with the troika of the European Commission. Csilla Kiss's paper "Of the Past Let Us Make a Clean Slate. The Lack of a Left-Wing Narrative and the Failure of the Hungarian Left" deals with the recent situation in Hungary, which along with Poland, is a favourite example for liberals to show that communism is to blame for populism and anti-democratic sentiments. The paper claims that the Hungarian Socialist Party's lack of a coherent politics of history "is unable to give a leftist response to the political right's approach to national history" (p. 24). It mainly reconstructs right-wing political history and Hungarian history as an objective set of events (a common approach in this volume) to conclude that "amnesia and forced compensation exhibited by the 'ashamed' left, which denies that the period had any progressive features, caused internalization of the guilt attributed to them by the right" (p. 30).

A comparative component is offered by the second paper titled "Communist Successors and Narratives of the Past: Party Factions in the German PDS and the Russian CPRF, 19902005", co-authored by Thorsten Holzhauser and Antony Kalashnikov. Focusing on two very different national cases, the article traces memory discourses to examine factors that shaped the identity and defined the strategy of successor parties in Germany and Russia. The authors 
mediate between the internalist (forces within a party) and externalist (institutional and sociopolitical contexts) explanations (p. 41). Despite many differences, "the Russian and German successor parties were able to capitalize on nostalgic feelings among those unconvinced by anti-communist elite discourses" (p. 59) at the same time serving anti-Western sentiments among their voters. While in Russia, the strategy was to defend the communist successorship against challenges from other parties and implement a "national liberation" program, in Germany it was to downplay PDS's monopolistic status as the communistsuccessor party. The authors ultimately appear to favour underlying internalist explanations over externalist ones for the party's political choices.

The last article from this section deals with responses of the radical left after the collapse of the Eastern Bloc. Walter Baier, in "The Memory and Identity of the Western European Left in the Light of European Integration", looks at how the Party of the European Left dealt with its historical precedents, the communist movement and Soviet system's final collapse. The assumption here is that the radical left can be treated as a "communist spectrum", although the term as such is no longer in use (pp. 78-79). It mainly provides a brief history and intellectual background of the radical left in Europe and its relation to the Eastern Bloc. The main theme is how Eurocommunism arose as a concept and led to the creation of a common leftist European group. Its attitude towards the Eastern Bloc might be summarised in a predictable manner: that the western Left distanced itself from Stalinism and any non-democratic practices. What is interesting is that we definitely get a first hand account, as Baier was to some extent a participant of the processes he describes. For over a decade, he was the national chairman of the Communist Party of Austria, a fact which is also discussed in the last section of the volume (p. 274). He was also the political coordinator of the transform!europe, which supported both the publication of the volume being discussed and the initial conference behind it.

The second section shifts the focus to socialist and post-socialist memorial landscapes by examining case studies from the former Soviet Bloc, mainly in a comparative perspective. Aleksandra Kuczyńska-Zonik offers insight into the fate of Soviet monuments in Poland, Lithuania and Ukraine, which are defined as objects and places commemorating Soviet soldiers, heroes and leaders of the socialist regimes or expressions of brotherhood with the USRR. While she treats these objects as monumental propaganda, she also acknowledges that this was typical for establishing any new political system. De-Sovietization meant purification of public space; it was "a symbol of moral renewal and the negation of the previous regime and a symbol of a struggle against corruption and collaboration" (p. 101). Kuczyńska-Zonik reconstructs the typical scenario when monuments were demolished or removed and replaced by statues commemorating national aspects of history. However, differences among the examined countries reveal that Polish municipalities have had to remove all symbols of state socialism, while in Lithuania, the law was less restrictive and fuelled the rise of socialist tourism. She 
concludes that in all the examined contexts we are "gradually witnessing a changing approach to recognition as a social historical heritage and a new appreciation of the monuments as a part of art history".

Another contribution of Stanislav Holubec also offers a comparative approach. The paper titled "Lenin, Marx and Local Heroes. Socialist and Post-Socialist Memorial Landscapes in Eastern Germany and Czechoslovakia" starts with a historical introduction and careful comparative section, which together trace Nazi monuments, and take up the majority of the paper. Holubec argues that his selected cases have much in common with each other and contrast with other communist dictatorships. High industrialization, strong working-class parties, evangelic religion, indigenous traditions of communism in East Germany and Czechoslovakia contrast with the very rigid regimes, revolutionary transitions and changes of boards of the other countries (pp. 122-123). We get an insight into the memory cultures of two cities comparable in size, history, position in their national economies and importance in their cultural landscapes: Jena and Hradec Kralove. These detailed case studies lead to broader conclusions: "Czechoslovakia was not only a harder line country than Poland or Hungary but matched the GDR in this respect. The degree of street renaming and destruction of memorials after 1989 indicates that the public and authorities of the former GDR were comparatively moderate in dealing with the defeated communism. On the other hand, in its anti-communism, the Czech Republic equalled Poland, with Slovakia standing somewhere in the middle" (p. 136).

The last paper from this section sets its focus solely on Russia. Ekaterina V. Klimenko's "The Politics of Oblivion Repression, Collective Memory and Nation-Building in Post-Soviet Russia" demonstrates the communist past as seen more positively in Russian public opinion than in most Eastern European societies. She examines the evolution of the strategies of conceptualization of past repression employed by both the state and civil society in the postSoviet period and how it was exploited in the process of nation-building and constituting national identity (p. 142). She shows how the public interest in USSR history during the period of perestroika and early 1990s arose, and how taking responsibility for the memory of repression was the strategy of conceptualizing it. The development of a "grand narrative" meant building a great nation and was based on neglecting the local and ignoring the global: "It disregards 'small' stories of 'little people' and is at the same time focused on Russia's 'special historical path"' (p. 157). This grand narrative focused on the heroic rather than the tragic events in the past. Actually, both Russian civil society and government moved from commemoration of the repression to a more or less successful attempt to forget it.

The longest and most diverse third section concentrates on the narratives of the communist parties in power. All five papers deal with state-socialism's own past. We get an insight into the memory wars inside the People's Republic in Jakub Szumski's “What Happened in 1980? Memory Forging and the Official Story of Martial Law in the Polish United Workers' 
Party" and Agnieszka Mrozik's "We Must Reconstruct Our Own Past. 1960s Polish Communist Women's Memoirs-Constructing the (Gender) History of the Polish Left". Szumski's research focuses on a moment of political crisis during the "Solidarity Revolution" and the introduction of martial law. A power shift in the ruling communist party was considered as the time when a new leader created the official vision of what happened. The author offers a literature review and very detailed description of party realities to underscore that "a shift towards basic values and themes, touched upon national and universal mythology and thus was very effective" (p. 185). This claim puts a clash of historical narratives at the centre of a tumultuous moment, which leads to the conclusion that "emotion and lack of reason originating in disappointment with the former leadership and discontent with the political and economic crisis led to unsupervised social and political activity" (pp. 184-185).

Mrozik's contribution touches upon a very interesting gender theme, absent from previous sections. In particular, she deals with women's autobiographies published in 1960s, after de-Stalinization. During the Gierek era, representations of communist women's experiences served to purify the idea of communism and to return it to its roots. Stories of female communists, engaged and active before the war, who often took important positions precisely during the Stalinization period served as a critical intervention into contemporary reality and a tool of communist identity revival. However, the women themselves were marginalized by the political change their memoirs served to legitimize and were even stereotyped as "aunts of the revolution". Their stories were creating a common history and constructing the Polish workers' movement and leftist traditions. As one of the women stated: "What I would fear most for Poland is instilling passivity and indifference in the minds of the youth toward matters of collective life, toward social afflictions" (p. 195). The theme as such draws readers' attention to the crucial issue of the role of gender with the memory police.

A repeating theme in the contributions was the communist romance with nationalism, especially in the later decades. The Romanian case discussed by Monica Ciobanu is probably the most extreme example of this. She focuses on Gheorghiu-Dej's political project and its legitimation both before and after Ceauşescu's rule. In Mrozik's paper, this story deals with one of the oldest generations of communists who managed to put communist ideals into practice by building a state. A large part of Mrozik's paper is dedicated to an overview of the 1989 revolution and its political aftermath, followed by a re-examination of the history of Gheorghiu-Dej's rule from 1948 to 1965 in the context of the post-1989 politics of memory. The latter is seen as a struggle to construct a national version of socialism and link its identity to a national narrative both before and after 1989. Ciobanu explains the post-1989 instability and volatility of public opinion by the dominant narratives of trauma, national suffering and victimization. However, she adds: "the present international political context dominated by growing Euroscepticism and the rise of extreme right-wing populist movements, which stand 
in sharp and ominous contrast to the enthusiasm and commitment to the liberal democratic project of the first years after 1989 (...) is likely to generate a more sympathetic feeling for the communist past among a significant section of the population" (p. 238). The cases of Hungary and Poland definitely do not support this argument, which might suggest an interesting comparative study.

Darina Volf's chapter "Constructing New Friends and Enemies. Rewriting Czechoslovak History After the Communist Takeover" also deals with the post-1948 period, but not from the post-1989 perspective. She examines public discourse on the "imperialist" role of the US in the pre-war period and in the 1940s. With the enforced establishment of the communist interpretation of Czechoslovak history after 1948, not only did historical images of the US and the Soviet Union change but important events in Czechoslovak history related to both superpowers were also reinterpreted. The limitations of the past narratives were revealed by the tempo with which banned historical images re-emerged after the Prague Spring. Volf concludes that all in all, it proved impossible to erase all positive memories of the US role in Czechoslovak history.

The last, closing chapter of the whole volume sets its focus on Russia in in the 1920s. Oksana Klymenko reconstructs how memoirs from the October Revolution served to legitimize Bolshevik power. She traces efforts to present it as an uprising and later as a revolution, and not as a coup. She sees it as a "memory project" establishing certain frameworks for remembering, which involved the gathering of memoirs from revolutionary participants: from famous activists and members of the Communist Party to workers and poor peasants. We can see here some similarities with the diary movement in Poland ${ }^{1}$ and the women's stories examined by Mrozik. In the Russian case, the attempt was implemented by the Committee on the History of the October Revolution. Klymenko disagrees that we can see those early attempts as creating an empire of memory, but she argues that it did establish a model for future campaigns to propagate the desired manner of seeing and writing history.

On the one hand, I appreciate setting our focus on communist memory policies in the region and Western Europe. On the other, I lack the enthusiasm of another book reviewer, Kathlyn Ghodsee, who underlined the "desire to challenge the totalitarian thesis about twentieth-century state socialism in Eastern Europe" and "critical nuancing of the recent past, undertaken by young scholars in the region" (Ghodsee 2018). Yes, authors assure the reader, that they treat communism as any other modern political movement and include modernization attempts, anti-colonialism and inclusive (or even emancipatory) moments of the communist movement, but a basic assumption about the role of official policies is often simplified into a

\footnotetext{
1 The diary movement or the so-called the Polish method developed by Florian Znaniecki and Ludwik Krzywicki in 1920s, public competitions for people' memoirs gained popularity especially in postwar Poland.
} 
"we-they" division. Despite Orwell's aforementioned quote, which obviously does not need to automatically indicate a totalitarian approach, the introduction begins with the blunt statement that citizens perceived the official vision of history as "one big lie" (p. 2). The bare choice to focus on communist memory politics instead of terror or repression does not seem revisionist. Furthermore, periodization, for example, is not questioned but reproduced as is the assumption that official discourse was propaganda. The question of propaganda seems especially interesting when we think about a possible comparison with contemporary right-wing or liberal policies. To what extent we see memory politics as a universal tool for any attempts to hegemonize discourse or does it truly depend on a political background of the possible hegemon? If we agree that every system of governance has its official version of history, then what remains different for Eastern Europe?

The volume's construction follows a standard scheme for memory studies: reconstructing a certain subject's policies in a selected period of time or examining how the memory of some event was constructed. All in all, it offers a set of localised, even narrow, historical case studies. Because of the detailed historical accounts, particular contributions may seem hermetic for a wider audience. Many also present historical background as somehow objective and separate from the historical politics, while obviously that is not a case. The narrative is detailed on the level of specific cases, but fragmented overall. To make my criticism less sever, let's keep in mind that we are talking about a historical work, reach in data and details. And to some extent, this is inevitable in any edited volume, but more work could have been done to negotiate a common meaning with the authors and to summarize the collected contributions (There is no summary, just a list of contributors.) A more critical voice that reviewed the initial conference behind the volume, resonates with my own doubts more strongly than Ghodsee's enthusiasm (Horeni 2016). I do not mind the rather openly leftist profile of the book's origin, to which Horeni pointed. But I do agree that it should be stated more clearly. Transform!europe is a network of organizations active in the field of political education and critical scientific analysis, and is the recognised political foundation corresponding to the Party of the European Left. Furthermore, much of Horani's criticism, articulated just after the conference, was not overcome during collaboration on the edited volume. I also agree with her other crucial point regarding the very limited coherence between papers and the lack of a common theoretical or methodological frame. All contributions, although dealing with similar issues, refer to different theoretical concepts like Keith Wilson's "memory forging" or the "heritagization" proposed by Kevin Wals, and even the usage of the words "communism", "socialism", "state-socialism" or even "left" does not seem to be negotiated or somehow standardized among the authors.

My very last remark does not address this particular book, but the wider publishing strategies set. For example, according to the new list of publishing houses issued by the Polish 
Ministry of Higher Education, the authors' decision to publish with Routledge is actually a good strategy for how to produce knowledge effectively - and gather points for Ministry's evaluation. However, while observing prestige hierarchies in the US where commercial publishing houses are not very respected and knowing the problematic role of corporations like Reed-Elsevier or Taylor \& Francis (like the Cost of Knowledge movement), I see a worrying trend of both: pushing edited volumes as a form, and younger authors as contributors towards commercial presses. This is problematic and needs to be both underlined and repeated. We have a commercial publishing press offering the volume for a price of 115 pounds, which is an amount of money devastating not only for any faculty member's private budget but also for those of libraries in the region. For example, this is almost 550 Polish zlotys - 15 percent of a median salary in Poland (3511 PLN) and 14,3 percent of a PhD's statutory earnings (Ministerstwo Nauki i Szkolnictwa Wyższego 2016). This is by no means a criticism of the editors or contributors, but of the publishing system, academic evaluation and its structural determinants. 


\section{References}

Bernhard, Michael H. and Jan Kubik (eds.). 2014. Twenty Years after Communism: The Politics of Memory and Commemoration. Oxford-New York: Oxford University Press, USA.

Dobre, Claudia-Florentina and Cristian Emilian Ghita (eds.). 2017. Quest for a Suitable Past: Myth and Memory in Central and Eastern Europe. Budapest-New York: Central European University Press.

Ghodsee, Kristen. 2018. "Review of Mrozik and Holubec, 'Historical Memory of Central and East European Communism”,. H-Socialisms | H-Net Reviews, July. http://www.hnet.org/reviews/showrev.php?id=52553.

Horeni, Karina. 2016. "Review: Historical Memory of Central and East European Communism 14.11.2015-15.11.2015 Prague”. H-Soz-Kult, 2 March. http://www.hsozkult.de/conferencereport/id/tagungsberichte-6373.

Ministerstwo Nauki i Szkolnictwa Wyższego. 2016. "Warunki wynagradzania za pracę i przyznawania innych świadczeń związanych z pracą dla pracowników zatrudnionych w uczelni publicznej". MNiSW.

Mink, Georges and Laure Neumayer. 2013. History: Memory Games. Basingstoke: Palgrave Macmillan.

Mitroiu, Simona. 2015. Life Writing and Politics of Memory in Eastern Europe. Oxford: Oxford University Press.

Ochman, Ewa. 2013. Post-Communist Poland - Contested Pasts and Future Identities. Hoboken: Taylor and Francis.

Pakier, Małgorzata and Joanna Wawrzyniak (eds.). 2016. Memory and Change in Europe: Eastern Perspectives. New York: Berghahn Books.

Sindbæk Andersen, Tea and Barbara Törnquist Plewa (eds.). 2016. Disputed Memory: Emotions and Memory Politics in Central, Eastern and South-Eastern Europe. Boston: De Gruyter.

Törnquist Plewa, Barbara (ed.). 2016. Whose Memory? Which Future? Remembering Ethnic Cleansing and Lost Cultural Diversity in Eastern, Central and Southeastern Europe. New York: Berghahn Books.

Wulf, Meike. 2016. Shadowlands: Memory and History in Post-Soviet Estonia. New York: Berghahn Books. 
Agata Zysiak - assistant professor at University of Warsaw, a sociologist of culture. Her research interests include historical sociology, biography, and modernity in Eastern Europe. She is the author of the award-winning book about the socialist university and upward mobility in postwar Poland, Punkty za pochodzenie (Points for Social Origin, 2016), and co-author of the recent volume From Cotton and Smoke: The Industrial City and Discourses of Asynchronous Modernity 1897-1994 (2018). In 2017-2018 a member at the Institute for Advanced Studies, Princeton. Currently, she is a visiting scholar at the Weiser Center for Europe and Eurasia at the University of Michigan, where she continues her comparative research on the working class in Detroit and Lodz.

\section{ADDRESS:}

Instytut Studiów Społecznych

Uniwersytet Warszawski

ul. Stawki 5/7,00-183 Warszawa

EMAIL: a.zysiak@uw.edu.pl

Citation: Zysiak, Agata. 2019. "How Communists Wanted to Remember Communism” Praktyka Teoretyczna 1(31): 156-167.

DOI: $10.14746 /$ prt.2019.1.8

AUTOR: Agata Zysiak

TYTUŁ: Jak komuniści chcieli, aby pamiętano komunizm

ABSTRAKT: Prezentowany tekst to esej recenzyjny na temat książki Historical Memory of Central and East European Communism (pod redakcją Agnieszki Mrozik i Stanislava Holubeca, Routledge 2018).

SŁOWA KLUCZOWE: polityka pamięci, komunizm, państwowy socjalizm, esej recenzyjny 